\title{
Die rol van kapitaal in die ekonomiese groei en ontwikkeling van onderontwikkelde
}

\section{gebiede*}

\author{
Inleiding.
}

In die teorie oor ekonomiese groei speel kapitaal 'n besonder prominente rol. Kapitaal met die daarby behorende tegnologiese ontwikkeling, word beskou as die belangrikste enkele faktor verantwoordelik vir die hereiking en instandhouding van 'n "ten volle ontwikkelde" volkshuishouding.

Ook in die praktyk van ekonomiese groei word kapitaal beskou as die sleutel vir alle moontlikhede tot 'n vergroting van die produksieomvang en 'n verhoging van die lewenstandaard. Byna daagliks word in die daghlad- en finansiële pers verwys na die groot behoefte aan binne- en huitelandse kapitaal vir die sogenaamde onderontwikkelde gebiede.

Waarskynlik is hierdie stand van sake tot 'n mate te wyte aan die relatief maklike aanwyshaarheid van kapitaaltekorte teenoor die moeiliker taak om aan te toon wat die nie-materiële faktore is wat noodsaaklik is vir 'n verhoging van die peil van ekonomiese aktiwiteit, soos byvoorbeeld die rol van arbeidsbekwaamheid, die aanwesigheid van voldoende entrepreneurs met die nodige agtergrond en ervaring om dic produksieproses te organiseer, die bereidwilligheid en vermoë van die gemeenskap om aan te pas by die veranderde produksiestruktuur, ens.

Met die hierna volgende bespreking sal 'n poging aangewend word om die belangrikheid van kapitaal as 'n faktor in die ekonomiese groei en ontwikkeling van onderontwikkelde gebiede na waarde te skat. Om hierin te slaag moet egter eers duidelikheid oor 'n aantal begrippe verkry word.

\section{Begrippe en definisies.}

In die spraakgebruik, maar selfs in die wetenskaplike literatuur, gebeur dit dat begrippe sonder nadere aanduiding gebruik word. Twee van hierdie begrippe wat gewoonlik as ekwivalente aanvaar word, t.w. „ekonomiese groei” en „ekonomiese ontwikkeling”, vereis die aandag.

\section{Ekonomiese groei en ontwikkeling.}

I) proses van verandering in 'n volkshuishouding, wat die onderwerp van 'n bespreking oor ekonomiese groei en ekonomiese ontwikkeling

\footnotetext{
- Iesing gehou voor die Afrika-seminaar van die P.U. vir C.II.O. op 21 Maarl 1962.
} 
vorm, is duidelik onderskeibaar en moet ook vir 'n duidelike uiteensetting onderskei word in kwantitatiewe en kwalitatiewe veranderinge.

Kwantitatiewe veranderinge kan plaasvind sonder dat die struktuur van die volkshuishouding enige kwalitatiewe veranderinge hoef te ondergaan, net soos wat die gewig van 'n mens kan toe- of afneem sonder dat 'n verandering in die wyse van funksionering van die menslike liggaam hoef in te tree. Hierdie kwantitatiewe veranderinge kan aangedui word met groei (wat in beginsel ook negatief kan wees) en wanneer dit gaan om kwantitatiewe veranderinge binne 'n bepaalde ekonomiese struktuur kan die begrip ekonomiese groei dan ook gebruik word.

Daarteenoor staan kwalitatiewe veranderinge wat gekoppel kan word aan die veranderinge van 'n bepaalde struktuur. Hierdie kwalitatiewe veranderinge kan aangedui word met die benaming ontwikkeling en toegepas op veranderinge in die ekonomiese struktuur kan dus gepraat word van ekonomiese ontwikkeling.

'n Enkele voorbeeld kan die hegrippe miskien beter verduidelik. Wanneer die inkome per hoof van die bevolking in 'n land toeneem, is daar sprake van ekonomiese groei; wanneer privaatondernemings as gevolg van die nasionalisering daarvan, plek maak vir staatsheheerde instellings word die ekonomiese struktuur kwalitatief verander vanaf 'n kapitalistiese na 'n sosialistiese of selfs 'n kommunisticse volkshuishouding en is daar sprake van ekonomiese ontwikkcling. Die begrippe groei en ontwikkeling dui egter nie sonder meer op gewenste veranderinge nie, soos wat duidelik spreek uit die gees waarmee 'n verandering in die ekonomiese struktuur soos in die voorbeeld genoem, deur 'n kapitalis bejeen sal word.

Met die voorgaande is egter nog geen definisie gegee van wat ekonomiese groei presies beteken nic. Ekonomiese groei kan gedefiniecr word as enige proses wat 'n langtermyn kwantitatiewe verandering van 'n bepaalde ekonomiese struktuur tot gevolg het, d.w.s. die werking van verskillende kragte in die ekonomiese lewe wat 'n kwantitatiewe verandering binne die bepaalde struktuur tot gevolg kan hê. Gewoonlik word hierdie groei gemeet in terme van 'n verandering in die reële inkome per hoof van die bevolking en/of in terme van die peil van die reële volksinkome (indien aanvaar word dat die bevolking konstant bly of in alle geval nie vinniger verander as die inkomepeil nie).

$\mathrm{Na}$ analogie van die voorgaande definisie kan die volgende definisie van ekonomiese ontwikkeling gegee word: Enige kwalitaticwe verandering van die ekonomiese struktuur van die gebied.

Onderontwikkelde gebiede.

Omdat die bespreking betrekking het op onderontwikkelde gebiede, 
is dit nodig om duidelik te stel wat met 'n onderontwikkelde gebied bedoel word. 'n Algemene definisie is egter in die verband baie moeilik omdat gebiede wat normaalweg as onderontwikkelde gebiede bestempel word, soveel onderlinge verskille vertoon en reeds verskillende stadiums in die proses van groei bereik liet. Die enigste oplossing is dus om 'n aantal helangrike eienskappe op te noem wat kenmerkend is van alle gebiede wat normaalweg as onderontwikkeld bestempel word en om aan die hand daarvan te besluit of 'n bepaalde gebied onderontwikkeld is of nie.

'n Onderontwikkelde gebied is dan enige gebied ten opsigte waarvan 'n aantal van, of al die volgende eienskappe ${ }^{1}$ ) geld:

1. Landbou en/of mynbou lewer die belangrikste enkele bydrae tot die volksinkome van die gebied.

2. 'n Neiging tot werkloosheid as gevolg van gebrekkige indiensnamemoontlikhede buite die landbou.

3. In die landbou self 'n lae opbrengs per arbeider.

4. Beperkte kapitaalvoorraad per arbeider.

5. 'n Lae per capita-inkomepeil, met die grootste deel van die volks. inkome toegedeel aan die laer inkomstegroepe.

6 . 'n Lae peil van binnelandse besparing en die spare wat nog plaasvind is gewoonlik nie beskikbaar vir investerings in nywerhede nie.

7. 'n Besonder loë persentasie van die privaatuitgawes word op 'n heperkte aantal voedselsoorte bestee.

8. Uitvoer van slegs landbouprodukte en ander grondstowwe in onverwerkte vorm

9. 'n Swakontwikkelde kredietmark.

10. Slegs 'n klein deeltjie van produksie word hemark, die grootste deel word deur die produsent self verbruik.

11. Lae opbrengs per produksiefaktor gebruik.

12. Onvoldoende opleidingsfasiliteite vir tegnici.

13. Swak vervoer-en kommunikasiegeriewe.

Uit die voorgaande is dit egter duidelik dat met onderontwikkelde gebiede ' $n$ relatiewe begrip ter sprake kom, aangesien die maatstaf eintlik geleë is in die ekonomiese struktuur van die moderne industriële lande van die Weste. Volgens hierdie maatstaf word dus eintlik aanvaar dat die huidige Westerse volkshuishoudingstipe ook die gewenste tipe is vir alle gebiede wat nog nie aan die eienskappe daarvan beantwoord nie -- en dit is nie sonder meer waar nie!

1) Vir 'n vollediger lys van kenmerke van onderontwikkelde gebiede, sien Harvey Leibenstein: Economic Backwardness and Economic Growth, 1957, pp. 40-41. 
Die kenmerkende eienskappe van so 'n onderontwikkelde gebied kan egter opgesom word in die volgende funksionele verbande:

(i) 'n Verbruiksfunksie, sodanig dat verbruik toeneem by 'n toename in die reële inkome van die gemeenskap en wel sodanig dat in die geval van die laer inkomstegroepe die toename in verbruik feitlik eweredig is met die toename in die inkome van daardie groepe, terwyl in die hoër inkomstegroepe die toename heolwat minder as eweredig is met die toename in liulle inkomes.

(ii) 'n Investeringsfunksie, sodanig dat investerings toencem hy 'n toename in die reële inkome maar minder as eweredig daarmee.

(iii) 'n Produksiefunksie, sodanig dat 'n toename in investerings 'n toename in die volksproduksie (opbrengs) tot gevolg het, wat verder afhanklik is van die bestaande kapitaalvoorraad, van die omvang van die investerings, van die houding teenoor ekonomiese groei by die bevolking en van die ontwikkeling van die tegnologie in die rigting waarin die investerings plaasvind - die produktiwiteit van die kapitaalgoedere dus.

\section{Kapitaal, investering en belegging:}

Tot dusver is reeds gebruik gemaak van die hegrippe kapitaal, kapitaalgoedere en kapitaalvoorraad, sonder dat 'n aanduiding gegee was wat presies daarmee bedoel word. 'n Nadere bepaling van die begrippe is egter nodig.

In die alledaagse spraakgehruik word met kapitaal gewoonlik verwys na finansiële of geldkapitaal -- die hoeveelheid geld waaroor 'n persoon dus beskik word sy kapitaal genoem. Hierdie begrip moet egter deeglik onderskei word van die begrip kapitaal soos deur die ekonoom gebruik. In die lg. geval word met kapitaal verwys na die voorraad goedere waaroor beskik word met die oog op produksie en verbruik. Hierdie begrip word in die vervolg gebruik tensy spesifiek na finansiële kapitaal verwys word.

Aanwending van kapitaal beteken egter dat dic voorraad daarvan verminder met verloop van tyd. Om hierdie voorraad aan te vul, heteken om beskikkingsmag oor ander (meer) kapitaalgoedere te verkry en hierdic toename staan bekend as investerings. Wanneer die toename gedurende ' $n$ periode meer is as die vermindering van die voorraad a.g.v. verloruik (waardevermindering) word gepraat van netlo investerings.

Investerings moet egter onderskei word van beleggings. Met beleg. gings word bedoel die anwending van geld vir die verkryging van sekuriteite sodanig dat 'n voorafbepaalde konstante vergoeding daarop' ontvang word en dat dit sonder die moontlikheid van 'n verlies weer in geld omgesit kan word. 
Dit behoort duidelik te wees dat alle spare dus nie altyd omgesit word in investerings nie maar dat daar soms oppotting plaasvind, d.w.s. dat spare in die vorm van geld behou word sonder om daarmee 'n vergroting in die kapitaalvoorraad te bewerkstellig.

Omdat die klem in hierdie betoog verder op kapitaal val is dit nodig om iets meer te sê oor die kapitaalvoorraad, veral van onderontwikkelde geliede.

Probleme by die bepaling van die omvang van die kapitaalvoorraad.

Om iets sinvol te sê oor die kapitaalvoorraad van onderontwikkelde gebiede is dit nodig om in staat te wees om die omvang van hierdie kapitaalvoorraad te bepaal, en in dié verband is daar ' $n$ aantal belang. rike probleme wat onderverdeel kan word in probleme van 'n algemene aard en probleme wat kenmerkend is van onderontwikkelde lande.

\section{Algemene probleme.}

$\mathrm{Om}$ ' $\mathrm{n}$ beeld te kry van die omvang van die kapitaalvoorraad van 'n ondernening of van ' $n$ hele gemeenskap is dit nodig om die waarde van die voorraad te bepaal sodat nie net die fisiese hoeveelhede van kapitaalgoedere nie, maar ook die bruikbaarheid daarvan, gemeet kan word. Om hierdie waarde te bepaal kan op een van twee wyses te werk gegaan word. Of die waarde kan afgelei word deur die verwagte toekomstige opbrengs van die kapitaalgoedere te verdiskonteer teen 'n bepaalde diskontokoers tot ' $n$ waardesom in die hede, of deur die koste van die kapitaalgoedere teen 'n hepaalde rentekoers of rentekoerse te hereken vir die lewensduur van die goedere, d.w.s. vir die periode waarin 'n hepaalde hoeveelheid geld vir die gebruik van die goedere daarin opgesluit is plus die oorspronklike koste van die bate.

Albei hierdie metodes lewer egter 'n belangrike probleem op, en dit is dat albei subjektief van aard is en dus geen suiwer resultate warborg nie. In die eerste geval moet die verwagte lewensduur van die bate subjektief geskat word asook die opbrengs van hierdie bate gedurende die periode, en laasgenoemde moet dan teen die heersende rentekoers verdiskonteer word. Die skattings kan uit die aard van die feit dat dit skattings is, egter verkeerd wees terwyl die rentekoers en dus die wenslike verdiskonteringskoers, kan verander. In die tweede geval is die historiese koste van dic bate wel objektief bepaalbaar, maar ook hier moet die lewensduur geskat word. Die gevaar van ekonomiese veroudering of van veranderde vraag- en aanbodtoestande wat die bruikbaarheid van die hate bepaal, makk hierdie skatting egter uiters moeilik. Bowendien kan dic rentekoerse met verloop van tyd verander wat tot verdere onsekerhede in die skattingsproses kan lei. Die laasgenoemde metode kan dus in begin- 
sel slegs korrekte resultate lewer in 'n slatiese toestand, d.w.s. waar hevolking, verbruikersvoorkeure en produksieomvang en tegnieke nic verander nie. Hierdie veronderstellings is egter heeltemal onrealisties.

Soortgelyke probleme word ondervind by die bepaling van die waarde van netto investerings. Nie net die waarde van die toevoeging tot die kapitaalvoorraad moet bepaal word nie, mar ook die wardevermindering van die bestaande voorraad gedurende die periode.

Bowendien is dit ook 'n moeilike satk om in die praktyk te hepaal wat wel as 'n deel van die kapitaalvoorraad beskou moet word, en wat nie; die gevolg is dat die samestelling van die kapitaalvoorraad nie in alle lande dieselfde is nie. Wat as kapitaal beskou word, sal grotendeels afhang van die sosiale en ekonomiese omstandighede. ${ }^{2}$ ) Hierdie omstandighede bemoeilik egter internasionale vergelykings van kapitaalvoorraad.

\section{Probleme in die geval van onderontwikkelde gebiede.}

Veral die probleme van wát as kapitaal beskou moet word, is van wesentlike belang by die bepaling van die kapitaalvoorraad van onderontwikkelde lande. In ten volle ontwikkelde lande word die aankoop van duursame verbruiksmiddele hyvoorbeeld om praktiese redes as verbruiksuitgawes beskou, terwyl dit in die geval van onderontwikkelde gebiede eerder as kapitaal geklassifiseer moet word. Dit is hoofsaaklik die goval omdat hierdie duursame verbruiksgoedere dikwels ook gedeeltelik vir produksiedoeleindes aangewend word, vergelyk byvoorbeeld die rol wat die trapfiets speel as kommersiële vervoermiddel in sommige dele van Midde-Afrika.

Besondere sosiale omstandighede bemoeilik ook soms die berekening van kapitaal. Die mees sprekende voorbeeld hiervan is die posisie van beeste ten opsigte van kapitaalvoorraad. Normaalweg vorm dit 'n belangrike item in die landboukapitaal, maar sou dit korrek wees om beeste wat bloot net vir die bepaling van sosiale status aangehou word, of wat aangehou word om ,hobola" mee te betaal, of selfs wat as heilige diere vereer word en wat meer verteer as wat hulle produseer, te reken as kapitaal? Bowendien gee dit aanleiding tot gronderosie en 'n daling in die landbou-opbrengs.

Afgesien hiervan is daar in die geval van onderontwikkelde gebiede gewoonlik 'n belangrike gebrek aan statistiese gegewens - gedeeltelik a.g.v. swak statistiese dienste en gedeeltelik a.g.v. die feit dat kapitaal in vorme aangetref word waarin dit nie maklik is om hetroubare gegewens daaroor te bekom nic. So byvoorbeeld word die rol van die arbeidstyd

2) P. T. Bauer en B. S. Yamey: The Economics of Under-developed Countries, 1957, p. 27. 
in die instandhouding en verhetering van bestaande kapitaalgoedere, wat so tipies is in die onderontwikkelde gebiede - veral in die landbou nie by die kapitaalvorming in berekening gebring nie. Dit gebeur dus maklik dat slegs kapitaalvorming in die industrieë as kapitaalvorming aangemerk word en dat ekonomiese groei dus eintlik sinoniem word met industrialisasie, wat nie noodwendig die geval hoef te wees nie.

Die vraag is nou, wat is dan die werklike peil van die kapitaalvoorraad in onderontwikkelde gebiede en wat is die verband tussen hierdie kapitaalvoorraad en die produksiefunksie in daardie gebiede, m.a.w. hoe word die bestaande kapitaalvoorraad benut?

Die peil en aanwending van kapitaal in onderontwikkelde gebiede.

Peil van kapitaal:

Soos uiteengesit in die kenmerke van onderontwikkelde gebiede, hyk dit dat die peil van kapitaal per capita laag is. Bowendien word die rol van kapitaal in die produksiestruktuur van die gebiede, deur faktore wat verantwoordelik is vir die lae effektiwiteit van die kapitaal, beperk.

Die algemene gevolg hiervan is 'n lae peil van produksie en gevolglik ook 'n lae peil van verbruik per persoon, terwyl die verbruikerskeuses ook uiters beperk is. As gevolg van swak vervoer en oplergingsfasiliteite lei misoeste dan ook baie gou tot hongersnode.

\section{Rentekoerse:}

Die gevoly van die lae peil van kapitaal is dat die rentekoerse in hierdie gebiede hoog is. 'n Ander faktor hiervoor verantwoordelik, is die hoë risiko verbonde aan investerings of beleggings in hierdie gebiede a.g.v. die lae effektiwiteit van produksie en die swak finansiële organisasie en struktuur.

Hierdic hoë rentekoerse lei egter daartoe dat 'n poging aangewend word om finansiële kapitaal so goed moontlik te investeer.

\section{Kapitaal en produksie:}

Die skaarsheid van kapitaal en die daarmee gepaard gaande hoë rentekoerse lei daartoe dat kapitaal relaticf duurder is as arbeid en dat kapitaal dikwels tot 'n helangrike mate in die produksieproses deur arbeid vervang word. Dit bcinvloed dus die tipe produksie in die gebiede en lit beteken dat 'n kapitaalintensiewe (gemeganiseerde) produksieproses in hierdie geliede dikwels nie die mees eknuomiese proses is nie.

Hierdic arbeidsintensiteit neig om oral te heers, byvonrbeeld in verwerkingsnywerhele, in dic landbou on in die vervoerstelsel. 
Natuurlik-beskikbare materiaal neem ook dikwels die plek in wat kapitaalintensiewe produkte in die meer ontwikkelde gebiede inneem, dink in dié verband maar aan die rol van inheemse bome in die bestaan van die Bantoe in Midde-Afrika.

\section{Die verdeling van kapitaal tussen verskillende sektore:}

Die gewone standpunt van ekonome is dat die beperkte hoeveelheid kapitaal so aangewend moet word dat die grensproduktiwiteit van kapitaal in alle aanwendings dieselfde moet wees. Dit beteken egter nie dat die verhouding van kapitaal en ander produksiefaktore - die kapitaalintensiteit dus - in alle aanwendingsrigtinge dieselfde sal wees nie.

Dit kom daarop neer dat die kapitaal aangewend moet word in die produksierigtings waarin daar om tegniese redes nie 'n substitusie van kapitaal deur arbeid moontlik is nie.

Die gewenste toestand is cater, soos later aangetoon sal word, om die kapitaal van 'n onderontwikkelde gebied te konsentreer in een of in 'n paar belangrike produksierigtings waarin hierdie gebied vergelykenderwyse produksievoordele het bo ander gebiede, selfs al beteken dit dat daar nie noodwendig 'n gelyke grensproduktiwiteit in alle aanwendings. rigtings deur die kapitaal verkry word nie.

\section{Die plek van kapitaal in die groeiproses.}

Met die voorgaande uiteensetting in gedagte, is dit wenslik om nou in meer besonderhede aan te dui wat die plek van kapitaal in die groeiproses presies is.

In die ekonomiese literatuur word daar tans twee tipes benaderinge in die verband aangetref wat wesentlik van mekaar verskil.

Ten volle ontwikkelde teenoor onderontwikkelde gebiede:

Een groep outeurs ${ }^{3}$ ) maak gebruik van wat genoem kan word „,kapitaal-opbrengsverhoudings" om die plek van kapitaal en veral van toename in kapitaal in die groeiproses aan te toon, terwyl 'n ander groep ${ }^{4}$ ) gebruik mak van een of ander tipe produksiefunksie.

3) Ifieronder ressorteer outeurs soos: R. F. Ifarrol; Towards a D) namic Liconomics, 1936; E. V. Domar: Essays in the Theory of Economic Growth, 1957; N. Kaldor: Essays on Economic Stability and Growth, 1960).

4) Onder andere P. A. Sameulson: „The Evaluation of Social Income: Capital Formation and Wealth" in The Theory of Capital, 1961; R. M. Solow: „Notes Towards a Wickscllian Model of Distributive Shares" in The Theory of Capilal, 1961; W. Fellner: „Appraisal of the Labour-saving and Capital-saving Character of Innovations" in The Theory of Capital, 1961; en Dorfman, Sameulson en Solow: Liniear Programming and Economic Analysis, 1958. 
Soos reeds gestel, gaan dit by ekonomiese groei hoofsaaklik om die toename in die reële volksinkome. Volgens die eersgenoemde benadering word nou beweer dat die mate van verandering van die kapitaalgoederevoorraad (d.w.s. die netto investerings) gedeel deur die mate van verandering in die volksproduksie vir dieselfde periode, 'n goeie aanduiding gee van die plek wat kapitaal in die groeiproses moet inneem. Hierdie verhouding staan bekend as die grens-kapitaal-opbrengsverhouding $(\Delta \mathrm{K} / \Delta \mathrm{Y})$ en die algemene gedagtegang was vroeër dat hierdie verhouding min of meer konstant is met 'n numeriese waarde van 3 tot 4.5) Met ander woorde ' $n$ netto investering van R100 miljoen het 'n opbrengs van $R 25$ miljoen tot R33 $1 / 3$ miljoen tot gevolg. Verder is ook empiries bepaal dat vir die afgelope ongeveer 80 jaar ten volle ontwikkelde lande Iussen $10 \%$ en $15 \%$ van hulle jaarlikse volksinkome investeer ${ }^{6}$ ) (waarop 'n ophrengs van $3 \%$ tot $4 \%$ verkry word) d.w.s. 'n groeikoers van $3 \%$ tot $4 \%$ per jaar.

Dit is egter die geval in ten volle ontwikkelde lande en dit herus op die volgende veronderstellings:

(i) Dat die rentekoers 'n neiging tot langtermyndaling vertoon het, sodat die rentekoers relatief gedaal het tot die loonpeil en dat dit slegs 'n geringe langtermynstyging in $\mathrm{K} / \mathrm{Y}$ tot gevoly gehad het;

(ii) dat dic produksiefunksie berus op 'n aanname van konstante opbrengs per produksiefaktor verbruik en dus sodanig is dat dit dui op 'n konstante grens-kapitaal-ophrengsverhouding;

(iii) dat die invloed van tegnologiese veranderinge op die verhouding afhanklik is van die feit of die veranderinge kapitaalverbruikend, kapitaalhesparend of neutraal is - in die e.g. geval sal die verhouding toeneem, in die tweede geval sal dit afneem en in die laaste geval onveranderd bly - omdat daar 'n neiging tot kompensasie tussen kapitaalbesparende en -verbruikende veranderinge bestaan, sal die verhouding dus konstant bly;

5) Bruton: "Growth Models in Under-developed Countries", Journal of Political Economy, 1955.

6) Die empiriese syfers vir 'n ten volle ontwikkelde land sien daar min of meer soos volg uit: Netto investerings bedra omtrent $13 \%$ van die bruto volksproduksie. Verder beloop waardevermindering omtrent $7 \%$ van die volksproduksie. bruto investerings vorm dus omtrent $20 \%$ van die bruto volksproduksie.

Ilierdie $20 \%$ worl min of meer soos volg verdeel:

1. Behuising (privaat) $25 \%$

2. Openbare werke en dienstebedrywe $35 \%$

3. Nywerheid en landbou

1. Ilandel 
(iv) dat die samestelling van die produksie sodanig is dat daar nie met verloop van tyd meer kapitaalgebruikende goedere verbruik sal word nie - dat die verbruikersmaak dus met verloop van tyd nie sal wysig ten gunste van kapitaalgebruikende goedere nie.

Die vraag is nou hoedanig hierdie argument gewysig moet word in die geval van onderontwikkelde gebiede en wat die gevolge van so 'n wysiging op die rol van kapitaal in die ontwikkeling van onderontwikkelde gebiede sal wees.

Feitlik slegs die eerste veronderstelling waarop die gevolgtrekking van 'n konstante grens-kapitaal-opbrengsverhouding berus, geld ook in die geval van onderontwikkelde volkshuishoudinge.

Ad (i): Hoewel die rentekoers in hierdie gebiede aanvanklik kan neig om te styg sodra die moontlikheid van kapitalisering en meganisering van die produksie deur die inheemse bevolking besef word, kan aanvaar word dat rentekoerse oor die algemeen reeds hoog is (soos reeds aangetoon) en dat dit oor die langtermyn sal neig om te daal, selfs meer as in die geval van die ontwikkelde lande, en dat die langtermynstyging in $\mathrm{K} / \mathrm{Y}$ hier dus veel meer merkwaardig sal wees.

Let egter daarop dat lierdie toename in die grens-kapitaal-opbrengsverhouding nie verkry kan word deur 'n kunsmatige verlaging van die rentckoers nie, aangesien dit tot 'n vermindering in dic binnelandse hesparing en in die invloei van investerings uit die buiteland sal lei en dus 'n nog groter kapitaalskaarste tot gevolg sal hê.

$A d$ (ii): Die produksiefunksie in onderontwikkelde gebiede is sodanig dat daar geen sprake kan wees van 'n konstante opbrengs per kapitaalverbruik nie, maar veel eerder van 'n stygende opbrengs en dit lej dus ook daartoe dat die grens-kapitaal-opbrengsverhouding gaan neig om vinnig te styg indien groei eers eenmaal aan die gang is.

Ad (iii): Omdat kapitaal relatief skaars en duur ten opsigte van arbeid is, kan dit normaalweg verwag word dat veranderinge in die tegnologie tot 'n groot mate kapitaalbesparend sal wees, maar omdat die kapitaalvoorraad reeds die minimum is sal kapitaalbesparende veranderinge waarskynlik nie algemcen voorkom nie. Ook a.g.v. tegnologiese veranderinge sal die kapitaal-opbrengsverhouding dus neig om te styg.

Ad (iv): Omdat kapitaalverloruikende gocdere skaars is sal dit aan die heginstadium nic in groot aanvraag wees nie (omdat dit relatief onbekend is) maar sal die anvraag daarna metterlyd meer as proporsioneel toeneem met die toename in die verbruik (wat met 'n tocname in die reele volksinkome saamgaan). Hierdie tendens word in dic moderne lyd angemoedig deur die sogenaamde intemasionale demonstrasic- 
effek, $\left.{ }^{7}\right)$ l.w.s. die neiging wat hy die bevolkings van onderontwikkelde gebiede bestaan om die verbruiksgewoontes van verluruikers in die ekonomies ontwikkelde lande na te volg, veral ten opsigte van die verbruik van luukse verbruiksgoedere sodra hulle inkomste dit moontlik maak.

I)it kom dus alles daarop neer dat die grens-kapitaal-opbrengsverhouding in onderontwikkelde gebiede laer is as in ten volle ontwikkelde gebiede, dat hier dus proporsioneel minder kapitaal nodig is om 'n gewenste groeikoers te bereik en te handhaaf, en dat alle omstandighede gunstig is vir ' $n$ vinnige styging in hierdie verhouding. In feite gebeur dit egter nie maar leer die ondervinding 8 j dat 'n onderontwikkelde volkshuishouding dikwels vir dekades, selfs vir eeue, in 'n skynbaar stabiele ewewig kan voortbeweeg sonder enige tekens van groei, dat in die bestek van twee of drie dekades hierdie ewewig verbreek kan word, en dat daarna ekonomiese groei min of meer outomaties volg.

Hiervoor moet daar bepaalde redes wees en dié redes word gedeeltelik aangetref in dic kenmerkende eienskappe van onderontwikkelde gebiede en kan verder met behulp van algemene opvattings in die teoretiese ekonomie verklaar word.

By die bespreking van onderontwikkelde gebiede is reeds daarop gewys dat daar 'n aantal faktore aanwesig is wat, soos by nadere ondersoek sal blyk, stremmend op ekonomiese groei in die algemeen en op kapitaalvorming in die besondere inwerk. Die krag van hierdie stremmende faktore moet dus eers verbreek word voordat 'n langtermynstyging in ekonomiese aktiwiteit kan plaasvind.

Die faktore wat stremmend inwerk op die groei kan soos volg ingedeel word:

\section{a) Outonome veranderinge:}

(i) Outonome styging in die bevolking: Hiermee word veral gedink aan die inkomeverlagende uitwerking van 'n styging in die bevolking. Die per capita inkome en die per capita kapitaalvoorraad verlaag (indien alles verder onveranderd bly) by 'n styging in die bevolking.

(ii) Outonome gronderosie: 'n Ander voorbeeld van 'n outonome stremmende invloed is die verswakking van landbougronde a.g.v. die roetine-gebruik daarvan met 'n daling in die opbrengs per oppervlakte (by afwesigheid van grondbewaring) en in die per capita inkome in die landbou (indien alles verder konstant bly).

7) Ragnar Nurkse: Problems of Capital Formation in Under-developed Countries, Oxford, 1953, p. 68.

8) W. W. Rostow: The Process of Eiconomic Growth, Oxford, twcede druk, 1960, Hoofstuk XII. 
b) Geïnduseerde veranderinge:

Hiermee word faktore bedoel wat stremmend inwerk op die styging van inkome a.g.v. 'n vorige styging in die volksinkome. Voorbeelde hiervan is die volgende:

(i) Geïnlluseerde bevolkingstoename: 'n Styging in die volksinkome kan tot verleterde gesondheidstoestande en dus tot 'n laer sterftesyfer en 'n hoër hevolkingsyfer aanleiding gee. Die gevolg hiervan is 'n daling in die per capita inkome (as alles onveranderd hly).

(ii) Geinduseerde gronderosie: 'n Toename in die inkome kan lei tot 'n poging om die onmiddellike landbou-oplorengs nog verder te verhoog - as gevolg van die verhoogde pryse en dus winste wat volg op die verhoogde vraag na landbouprodukte, wat op die verhoogde inkome sal volg - waardeur die grond oorbewerk sal word on 'n langtermyndaling in die opbrengs per grondoppervlakte tot gevolg sal hê.

(iii) Geïnduseerde verbruik: 'n Styging in die inkome kan daartoe lei dat die internasionale demonstrasie-effek sterker op die voorgrond tree en dat verbruik - veral van luukse ingevoerde artikels - - vinnig sal toeneem, wat tot 'n daling in spare en dus in investerings sal lei.

c) Sosiale, politieke en ekonomiese omstandighede.

(i) Sosiale en politieke stagnasie: In die meeste onderontwikkelde lande moet die sosiale en politieke tradisies eers verbreek word voordat die gemeenskap ingestel raak op die moontlikheid van ekonomiese groei en ontwikkeling. Sosiale en godsdienstige rituecl lei dikwels tot ekonomies onverantwoorde dade, bv. die vernietiging van alle besittings van 'n oorledene. Dit strem kapitaalvorming en dus ekonomiese groei.

(ii) Risikodraging: Gewoonlik ontbreek die tipe persoon in onderontwikkelde gebiede wat bereid is om die risiko te aanvaar wat gepaard gaan met 'n verandering van die produksiestruktuur gedurende die groeiproses, en dit strem die groei.

(iii) Hoë grensgeneigdheid om te verbruik: Algemeen gestel is die grensgeneigdheid om te verbruik in onderontwikkelde gebiede baie hoog sodat 'n toename in die inkome feitlik nie aanleiding gee tot verhoogde spare en investerings nie.

(iv) Onverdeelbaurheid van produksiefaktore: Omdat 'n bepaalde produksieproses slegs in sy geheel aangepak kan word, verg dit groot gelyktydige investerings in bepaalde bedryfstakke, wat maklik aanleiding kan gee tot 'n ongebalanseerde ontwikkeling van die produksiestruktuur. Aan die ander kant sou 'n meer gelykmatige verdeling van 'n beperkte investeringsvolume waarskynlik in geen bedryfstak enige noemenswaardige resultate lewer nie.

Die voorgaande dui dus daarop dat enige groeistimulus, soos bv. 
toename in investerings, 'n toename in die volksinkome tot gevolg het, wat eenvoudig deur die bogenoemde faktore geabsorbeer word en wat die volkshuishouding in sy onderontwikkelde ewewigsposisie hou.

Nadere ondersoek van hierdie beperkende faktore lei egter tot die besef dat hierdie faktore almal 'n bepaalde limiet het waarbo die beperkende krag nie kan uitstyg nie.

Bevolkingstoename, hetsy of dit outonoom of geïnduseerd is, word bioties beperk tot ongeveer $4 \%$ op die langtermyn; 'n hoë graad van gronderosie lei tot die besetting van nuwe grond (indien dit beskikbaar is) of tot 'n gedwonge bewaringsboerdery: die hoë grensgeneigdheid om te verbruik, sowel as die verhoogde geïnduseerde verbruik bly net van belang totdat 'n groep van die inheemse bevolking bewus word van die potensialiteite van ekonomiese groei; die probleme van onverdeelbaarheid van produksiefaktore kan oorbrug word, mits die investeringsvolume groot genoeg is, ens.

Hierteenoor staan die feit dat alle investerings 'n inkomestygende uitwerking het, al is dit dan ook betreklik laag in lande met 'n lae geneigdheid om te spaar.

Waarop dit dus alles neerkom is dat onderontwikkelde lande ekonomies kan groei mits hulle 'n stimulus ondervind wat sterk genoeg is om die negatiewe groeikragte te verbreek en wat nog bowendien in staat is om kapitaalvorming moontlik te maak.

Eerste van alles beteken so 'n stimulus 'n verbreking met die oeroue lewenstradisies en die insig in die moontlikhede van ekonomiese groei vir die gebied by 'n groep van die bevolking. Hierdie breuk met die verlede is tans besig om onder invloed van internasionale omstandighede en a.g.v. die ontwaking van 'n nasionalistiese gees, in feitlik al die onderontwikkelde lande plaas te vind.

Hierbenewens moet hierdie stimulus 'n ekonomiese uitkyk op sake hy die bevolkings (of dele van die bevolkings) van die gebiede laat posvat - hulle moet dus rasionalisties begin dink oor dinge en die moontlikhede van ekonomiese groci vir hulle gebiede insien. Ook hiervan is daar reeds veel te bespeur.

Al wat dus ontbreek vir ekonomiese groei is die ervaring en tegniese kennis wat nodig is vir ' $n$ verandering in die produksiestruktuur en 'n groot genoeg volume van investering (gekonsentreer in bepaalde rigtings) om die ewewig van hierdie gebiede te verbreek en hulle op die weg te plaas van kapitaalvorming en langdurige ekonomiese groei.

Sonder die tegniese kennis en ervaring is die investerings wat gemaak word egter sinloos, aangesien dit nie teen 'n hoë produktiwiteit aangewend kan word nie.

Hieruit is dit dus duidelik welke belangrike rol kapitaal en veral 
kapitaalvorming in die ekonomiese groei van onderontwikkelde lande speel. Dit moet egter besef word dat kapitaal alleen nie kan aanleiding gee tot ekonomiese groei nie.

\section{Voorvereiste vir die benutting van kapitaal:}

Soos aangetoon is kapitaal nutteloos indien daar nie voldoende tegniese kennis bestaan om die kapitaalgoedere te benut nie. Hierdie tegniese kennis onthreek egter by die inheemse bevolkings van onderontwikkelde gebiede omdat dit met hulle ekonomiese, politieke en sosiale agtergrond, iets vreemd is waarvoor hulle ook geen aanvoeling het nie. Dit lei daartoe dat die waardevermindering van kapitaalgoedere hier teen 'n hoër tempo plaasvind as in ontwikkelde lande. Hierteenoor staan egter die feit dat kapitalalgoedere, a.g.v. dic gebrek aan nuwe goedere, nie ekonomies so maklik verouderd raak nie.

Dit is egter nie net nodig om tegniese vaardigheid in die hantering van kapitaalgoedere by die arbeid an te kweek nie maar ook om dic insig in die werking van ' $n$ kapitalistiese produksiesisteem te ontwikkel, en dit is veral in hierdie verband dat onderontwikkelde lande hulle grootste probleme ondervind. Dit is dan ook hier waar die begrip ekonomiese ontwikkeling na vore kom.

Meeste van die primitiewe volkshuishoudinge staan vreemd teenoor die kapitalistiese produksieproses. Die gevolg is dat daar 'n gebrek aan entrepreneursbekwaamheid bestaan wat die groei van die volkshuishouding op kapitalistiese basis haas onmoontlik maak.

Histories gesien was die oplossing geleë in die invoering van ondernemers uit die buiteland. Omdat 'n strewe na 'n maksimum korttermynvoordeel -.. wat kenmerkend is van die kapitalistiese entrepreneur van vroeëre dekades - hierdie ondernemers daartoe gelei het om die inheemse bevolking - a.g.v. hulle onkunde -- uit te buit, raak hierdie metode al hoe minder gewild.

Om hierdie probleem die hoof te bied het veral Amerika daartoc oorgegaan om tegniei op 'n tydelike basis aan die onderontwikkelde gebiede te verskaf, en om privaat buitelandse beleggings (wat onder hierdie omstandighede 'n daling vertoon) aan te vul met langtermynlenings op regeringsvlak.

Langs hierdie weg kry die inheemse bevolking dan geleentheid om die struktuur van hulle eie volkshuishouding meer kapitalisties te maak en om die beskikbare kapitaal reeds vanuit die staanspoor so volledig moontlik te probeer benut.

Die anwending van kapitalistiese produksieprosesse vereis egter ook die ontwikkeling van die nodige finansiële instellings. Gewoonlik gaan ekonomiese groei dan ook gepaard met die ontwikkeling van 'n 
behoorlike binnelandse kredietmark. Eers ontwikkel die algemene kredietinstellings soos hanke, versekeringsinstellings en houvereniginge, en dan die spesifieke kapitaalmarkinstellings soos aandelebeurse en gewoonlik in die laaste instansie eers die geldmarkinstellings soos aksepterings- en verdiskonteringshuise en ander daggeldinstellings.

Omdat dit gewoonlik makliker gaan om hierdie ondernemings, soos ook die ondernemingsvorme inherent aan die kapitalistiese produksie. proses, bv. openhare en privaatmaatskappye, tot stand te bring met behulp van Westerse privaatinisiatief, maar omdat die onderontwikkelde lande vandag meestal gekant is teen die toelating van Westerse privaat. inisiatief in hulle gebiede, bestaan die algemene neiging al hoe sterker vir die hetrokke inheemse owerhede om self die inisiatief te neem. Hieruit spruit egter vir die Westerse wêreld 'n leelangrike gevaar, omdat dit baie maklik daartoc kan lei dat die owerhede van hierdie jong lande so 'n belangrike aandeel in hulle volkshuishoudings kan verkry dat hierdie volkshuishoudings mettertyd sosialisties of selfs kommunisties kan word. Teen hierdie tendens in die ekonomiese ontwikkeling, moet die Weste egter haie streng waak, want hiermee verval die hoofdocl van die Westerse ekonomiese hulp aan onderontwikkelde gebiede, nl. om die gebiede teen die insypeling van kommunisme te beskerm.

Dit bring die argument op 'n stadium waarin dit nodig geword het om meer aandag te gee aan die wyses waarop kapitaalvorming in onderontwikkelde gehiede verkry kan word.

Kapitualvorming in onderontwikkelde gebiede.

In heginsel is daar twee hoofmetodes van kapitaalvorming vir enige land. Die eerste is binnelandse kapitaalvorming deur hinnelandse spare wat dan ook in die binneland geïnvesteer word. Die tweede is die instro. ming van buitelandse investerings. Aandag kan vervolgens aan elkeen van hierdie twee metodes geskenk word.

\section{Kapitaalvorming uit binnelandse bronne:}

Die peil van spare in onderontwikkelde gehiede is gewoonlik baie laag omdat, soos reeds aangetoon, die grootste deel van die inkome na die laer inkomstegroepe vloei wat 'n lae grensgeneigdheid het om te spaar. Groot grondbesitters spaar gewoonlik ook nie veel nie, terwyl dic klein grondbesitters wel probeer spaar maar hulle spare in hulle eie landbouproduksie investeer wat gewoonlik nie 'n hoë produktiwiteit lewer nie. Die enigste groep wat wel noemenswaardig spaar is ondernemers. Ondernemerswinste vorm dus dic belangrikste bron van binnelandse spare vir 'n volkshuishouding. Die feit dat die ondernemersklas in die 
onderontwikkelde geliede so gering is, is dus verantwoordelik vir die lae peil van spare en gevolglik ook investering.

Die anderkant van die saak is dat 'n hoë spaarneiging ook weer maklik tot oorproduksie kan lei. Omdat die inkome wat op verbruik bestee word a.g.v. die hoë spare verminder, sal die verbruiksvraag (die vraag na verbruiksgoedere) verminder en dit kan daartoe lei, veral omdat onderontwikkelde lande angewys is op die produksie van grondstowwe en verbruiksmiddele, dat die vraag laer daal as die produksie, wat werkloosheid tot gevolg kan hê.

Dit mag selfs gebeur dat 'n vinnige toename in investerings tot inflasie aanleiding kan gee. Aangesien die vermoë van die kapitaalgoedereindustricë nie in staat is om in die verhongde vraag te voorsien nie, tree prysstygings op en dit neig tot inflasie selfs al bestaan daar werkloosleid in die arbeidsektor.

Aangesien die groot leemte vir die toename in spare egter geleë is in die feit dat die groutste deel van die bevolking glad nie of nie voldoende spaar nic, word die vraag soms gestel of 'n onderontwikkelde gelied nie kan oorgaan tot 'n stelsel van verpligte spare nie. Hiermee word dan bedoel dat die owerheid 'n verhoogde belastingkoers moet hef en die ophrengs van die belasting dan moet gebruik om kapitaalvorming aan te help. Dit kom dus daarop neer dat spare gesosialiscer word. Dit is duidelik dat hierdie metode maklik tot algehele sosialisering kan lei. Dit verminder die beskikbare spare vir privaatinvestering en kan baie maklik tot 'n sodanige daling in verbruik lei dat dit tot werkloosheid en ckonomiese agteruitgang aanleiding kan gee.

in Alternatiewe benadering vir die owerheid sou wees om oor te gaan tot 'n stelsel van tekorte op die begroting, om sodoende dic peil van staatsuitgawes te vergroot sonder om helastings te verhoog. Die begrotingstekorte moet egter gefinansier word en indien dit deur die aangaan van binnelandse lenings gedoen word is die effek feitlik dieselfde as in dic geval van verpligte spare, nl. om dic spare vir privaatinvestering te verminder.

Word die tekorte aangesuiwer deur huitelandse lenings, ontstaan die gevaar van 'n inflasie indien die owerheid met hierdie fondse produksiefaktore wat reeds beset was, uit die privaatsektor, wegbic. Afgesien hiervan gaan dit in hierdie geval reeds oor 'n vorm van kapitaalvorming uit buitelandse bronne.

\section{Kapitaalvorming uit buitelandse bronne:}

Buitclandse bronne kan hoofsaaklik op vier wyses vir kapitaalvorming in die binneland benut word. Elkeen van hierdie metodes het sy eie probleme en voordele. Hierdic metodes is die volgende: 
a) Direkte investerings, d.w.s. investerings deur privaatondernemings van die buiteland in privaat binnelandse ondernemings.

b) Indirekte investerings, d.w.s. deur die privaatsektor van dic huiteland in regerings- of semi-regeringsprojekte in die binneland.

c) Regeringsinvesterings, d.w.s. lenings van 'n buitelandse regering aan dic binnelandse regering, en

d) internasionale investering, d.w.s. lenings van internasionale finansieringsorganisasies wat an die binnelandse regering of selfs aan privaatfinansierings- of -ondernemingsgroepe verstrek kan word.

Ad a): Direkte investerings kan op tweërlei wyse geskied, t.w. deur middel van die stigting van filiaalmaatskappye met die moedermaatskappy in die buitcland, en deur middel van groot hinnelandse privaatfinansieringsinstellings wat in dic buitelandse kapitaalmark optree. Hierdie metode het aan die beginstadium van ckonomiese ontwikkeling in meeste Afrikalande 'n helangrike rol gespeel maar begin onder die moderne bedeling van intipatie teen die sogenaamde imperialistiese lande, 'n minder helangrike plek inneem. Dit kan naamlik maklik lei tot'n mindere of meerdere mate van politieke afhanklikheid. Om hierdie probleem die hoof te lied kan die betrokke land vereis dat die meerderheid van die kapitaal van die ondernemings wat in die linneland gevestig word in die binneland gehou word, solat binnelandse beheer oor die ondememings uitgeoefen kan word.

'n Tueede nadeel aan direkte finansiering verbonde is dat dit kartel- of monopolievorming in die hand werk. $\Lambda$ an hierdie verskynsel kleef verskillende nadele. Die belangrikste is egter waarskynlik dat abnormale hö̈ winste na die buiteland vloei ten nadele van die kostestruktuur en die verdere kapitaalvorming in die binneland.

Direkte buitelandse finansiering deur middel van filiaalmaatskappye het verder die nadeel dat die buitelandse moedermaatskappye dikwels 'n heleid op dic filiaal afdwing wat direk in stryd is met die ekonomiese belang van dic bimeland. So iets gebeur bv. wanneer die moedermaatskappy self alle internasionale bemarking hantecr en dus die inisiatief van die filiaal ontneem om binnelandse markte te ontwikkel. 'n Ander moontlikheid is dat swak finansiële beleid of omstandighede die aktiwiteite van die filiaal aan bande kan lê, wat stremmend kan inwerk op die binnelandse ekonomiese groei. Bowendien kan die filiale 'n beleid volg wat in stryd is met die monetêre en ekonomiese beleid van die binnelandse regering.

Die laaste belangrike beswaar teen die buitelandsgefinansierde onderneming is dat alle uitvoerende poste vir buitelanders gereserveer word, sodat die inhlıemse bevolking nie maklik die geleentheid kry om geoefen te raak in die uitvoering van ondernemingsadministrasie en ondernemings- 
inisiatief nie - en dit is 'n legniek wat an geen tegniese skool of universiteit gedoseer of geleer kan word nie.

Ad b) en c): Indirekte en regeringsinvestering kan oor dieselfde kam geskeer word, want in lande wat nic op die goudstandaard is nie en daar is vandag geen land op die goudstandaard nic - is indirekte investering ten volle afhanklik van die regeringsheleid wat geforseer word, deur middel van wetgewing (V.S.A.) of deur middel van wisselkoerskontrole (V.K.).

$A d d)$ : Ten slotte gaan die internasionale finansiering gebuk onder 'n helangrike tekortkoming, naamlik die feit dat hoofsaaklik selflikwiderende lenings op hierdie vlak in aanmerking kom, d.w.s. alleen lenings waarop, 'n direkte inkomste verkry word wat voldoende is om rentebetaling en kapitaalterugletaling (finansiële kapitaal) te voorsien. Dit beteken dus dat finansieringshehoftes van die regerings vir projekte soos onderwys, hospitalisasie, padbou ens., nie voldoende deur lierdie kanaal voorsien kan word nie - 'n situasie wat gewoonlik 'n direkte oorsaak vorm vir belastingverhoging.

Internasionale instellings vir kapitaalvorming in onderontwikkelde gebiede:

'n Laaste paar opmerkinge is waarskynlik geregverdig oor die internasionale instellings wat kapitaalvorming in onderontwikkelde gebiede aanhelp.

Hierdie instellings kan in twee groepe verdeel word, t.w. instellings wat hulle fondse uit 'n hele aantal lande verkry en instellings wat hulle fondse uit bepaalde indiwiduele lande verkry.

Van die eerste groep vorm die volgende instellings dic belangrikste voorbeelde:

(i) Die Internasionale Monetêre Fonds: D)ie IMF wat sy ontstaan te danke het aan die konferensie te Bretton Woods (V.S.A.) gedurende 194.3 en 1944, het 'n heel besondere taak ten opsigte van die ontwikkeling van onderontwikkelde gebiede. Die Fonds voorsien nic in die kapitalbehoeftes van onderontwikkelde ledelande nie maar probeer om die lestaande finansiële struktuur van ledelande te stabiliseer deur aan die regerings lenings op kortlermyn te verskaf indien hulle 'n belangrike daling in hulle goud- en valutareserwes ondervind. Langs hierdie weg word die groot risiko van devaluasie vir buitelandse beleggers aansienlik verminder, wat die klimaat vir hicrdie beleggings in die ledelande dus gunstig stem.

(ii) Die Internasionale Bank vir Heropbou en Ontwikkeling: Hierdie Bank, ook bekend as die Wêreldhank, was ook 'n voortvlocisel uit die Bretton Woods-ooreenkoms. Die doel van die lank was hoofsatiklik 
Iweёrlei van aard, naamlik die ekonomiese rekonstruksie van Europese lande wat deur die Tweede Wêreldoorlog vemiel was en 'n poging tot die ontwikketing van ekonomiese onderontwikkelde lande, deur middel van die verskaffing van langtermyn buitelandse lenings. Die laasgenoemde Joel hel egter die belangrikste geword, aangesien die herophou in Europa kragtens die Marshall-hulpplan uit ander loromne gefinansier is.

Dic Bank verskaf alleen lenings aan aandeelhouers alle lede-lande van die IAl kan aandeelhoners van die Bank word. By verskaffing van lenings word nonkeurig ondersoek of die lenings wel tot die beste voordeel van die ekonomiese groei van die betrokke lande sal lei en daarvoor van strategiese loelang is.

Meestal word die lenings aan regerings verstrek en moet dit van 'n selflikwiderende aard wees. Waar die lenings aan privaat- of semiprivaat instellings verskaf word, word die staat gewoonlik gevra om terughetaling van dic lenings te waarborg.

Die grootste prohleem i.v.m. die aktiwiteite van die Bank is dat die fondse nie altyd voldoende is nie, en verder dat geen voorsiening gemaak word vir riskante lonings nie. I)ie laasgenoemde probleem is egter reeds gedeceltelik opgelos deur die instelling van 'n filiaal-organisasie van die liank.

(iii) Die Internasionale (ntwikkelingsvereniging: Hierdie filiaal van die Wêreldbank staan hekend as die International Development Association 111) 4 t en liet in 1960 lot stand gekom.

Gedurende die eerste jaar het die ID $\Lambda$ reeds 'n ledetal van 51 lande gelad met in subskripsie van bykans 906 miljoen dollar.

(iv) Die Development Assistance Group: Hierdie organisasie is in die lewe geroep op 'n konferensic te Parys gehou op 13 en 14 Januarie 1960. Jedelande van hierdie organisasie is België, Kanada, V.S.A., lrankryk, Italië, Japan, Portugal, Wes-Duitsland, V.K., Nederland en die Europese Ekonomiese Gemeenskap.

I) doel van die I)AG is die koordinasie van finansiële pogings met betrekking tot die ontwikkeling van onderontwikkelde gebiede en die skepping van 'n geleentheid tot onderlinge oorlegpleging tussen die lande wat sodanige hulp verleen met die oog op hespreking van probleme en verskaffing van tegniese lıulp aan ledelande.

$\Lambda$ fgesien van die voorgaande instellings is daar nog drie instellings wat vermeld moet word en wat onder die tweede groep ressorteer naamlik, die instellings van spesifieke lande:

(i) Die Amerikamse Uitvoer-Invoerbank: Die hoofdoel van hierdie bank is die voorsiening van lenings ter bevordering van die Amerikaanse uitvoere. Dour middel van hierdie hank verleen Amerika dan ook hulp 
aan verskillende onderontwikkelde lande, hetsy om hulle eic nitvoer aan te help of met die oog op politieke gewin.

\section{Die Commonwealh Development Hinance Company:}

Hierdie instelling is in 1953 for stand gelning met in kapital wat lwoofsaaklik deur die Bank van Fingeland (dic Brilse sentrale lank) verskaf is met die doet om onderontwikkelde lande van die Britse (Eemenebes tot ekonomiese ontwikkeling aan to help. Lenings van die CIDF(: word gewoonlik gegee vir projekte wat gedecltelik uit ander bronne van fondsc voorsien word.

\section{Die European Development Fund:}

Hicrdie Fonds is in 1958 gestig deur die ledelande van die Europese Ekonomiese Gemeenskap met die doel om tegniese en finansiële hulp aan onderontwikkelde geassosieerde gebiede van die Gemeenskap te verskaf. Vir 1960) was daar nie minder nie as 420 projekte wat vir oorweging aan die fonds voorgelê is, warvan $23 \%$ (in waarde) sosiale projekte ell $77 \%$ ekonomiese projekte behels het.

P.U. vir C.H.O.

F. J. du l'lessis. 